\section{Optimization of Conditions for Maximal Production of Recombinant Thermostable Cellulase from Thermotoga naphthophila using $E$. coli BL21-CodonPlus (DE3) as Expression Host}

\author{
Aisha Khalid ${ }^{1}$, Muhammad Tayyab ${ }^{1, *}$, Abu Saeed Hashmi', Tahir Yaqub², \\ Ali Raza Awan', Muhammad Wasim ${ }^{1}$, Shagufta Saeed ${ }^{1}$, Sehrish Firyal ${ }^{1}$ and \\ Abdul Rauf Shakoori ${ }^{3}$ \\ ${ }^{1}$ Institute of Biochemistry and Biotechnology, University of Veterinary and Animal \\ Science, Lahore \\ ${ }^{2}$ Department of Microbiology, University of Veterinary and Animal Science, Lahore \\ ${ }^{3}$ Department of Biochemistry, University of Central Punjab, 1 - Khayaban-e-Jinnah \\ Road, Johar Town, Lahore
}

\section{A B S T R A C T}

Current study was designed for the development of an economic and environment friendly mechanism for the production of thermostable cellulase. Production of cellulase was focused due to its diverse range of application in industry. In the present study, conditions were optimized for the maximal production of recombinant thermostable cellulase from Thermotoga naphthophila using BL21-CodonPlus (DE3) cells as expression host and pET28a as expression vector. Effect of various concentration of Isopropyl $\beta$-D-1-thiogalactopyranoside (IPTG), post induction time, effect of temperature and $\mathrm{pH}$ were examined for the maximal production of recombinant cellulase. The effect of supplementation of LB medium with additional carbon and nitrogen sources was also analyzed for maximal production of recombinant protein. Higher level enzyme activity was recorded at $25^{\circ} \mathrm{C}, \mathrm{pH} 7.0$ when the cells were induced with $0.5 \mathrm{mM}$ IPTG with $22 \mathrm{~h}$ post induction incubation. Supplementation of LB medium with $1 \%$ glucose and yeast extract enhanced the production of recombinant thermostable cellulase. Enzyme showed strong potential for its use in paper and poultry feed industry. Under the optimal conditions we could able to produce 48 $\mathrm{U} / \mathrm{mL}$ of recombinant cellulase.
\end{abstract}

\begin{tabular}{l} 
Article Information \\
\hline Received 07 January 2019 \\
Revised 01 March 2019 \\
Accepted 13 March 2019 \\
Available online 03 May 2019 \\
Authors' Contribution \\
\hline AK performed experiments. MT \\
planned and supervised the study and \\
provided guidance for manuscript \\
write-up. ASH and TY facilitated \\
the conduction of experiments. ARA \\
and MW helped in data analysis. SS, \\
SF and ARS helped in manuscript \\
write-up. \\
Key words \\
Recombinant cellulase, BL21- \\
CodonPlus (DE3), Thermotoga \\
naphthophila, Optimization of \\
conditions.
\end{tabular}

\section{INTRODUCTION}

$\mathrm{C}$ Cellulose is the most abundant organic compound on earth and is the principal component of plant cell wall (Wang et al., 2015). It is a homo-polymer of glucose where monomers are linked each other through $\beta-1,4$ glycosidic linkage (Kang et al., 2011). A variety of industrial and agricultural wastes have cellulose as a major component which can be transformed into simple sugar via the hydrolysis process. Two methods are available for hydrolysis of cellulose to its monomeric units. The chemical hydrolysis method requires the treatment of cellulose with strong acid under high temperature $>300^{\circ} \mathrm{C}$ at $25 \mathrm{MPa}$ which make this method as cost efficient with poor quality and low yield of final product (Deguchi et al., 2006).

\footnotetext{
* Correspondingauthor:muhammad.tayyab@uvas.edu.pk 0030-9923/2019/0004-1371 \$ 9.00/0

Copyright 2019 Zoological Society of Pakistan
}

Enzymatic hydrolysis method is preferred over chemical hydrolysis due to its environment friendly nature. Cellulases are biocatalyst required for digestion of cellulose under ordinary temperature and $\mathrm{pH}$ conditions which is not hazardous to environment (Koomnok, 2005).

On the basis of catalytic action, the cellulases have been divided into the three major classes including endoglucanases (EC 3.2.1.4), $\beta$-glucosidase (EC 3.2.1.21) and exoglucanase (EC 3.2.1.91) which are responsible for the de-polymerization of complex cellulose to simple glucose units (Karmakar and Ray, 2011). Cellulases have been immensely used in various industries including textile industry for improvement of fiber softness (Galante et al., 1998; Sreenath et al., 1996), in paper and pulp industry for refinement and strengthing of paper (Singh et al., 2007; Akhtar, 1994; Bhat, 2000), in bioethanol production for saccharification of lignocellulosic materials (Sukumaran et al., 2005; Kuhad et al., 2010; Gupta et al., 2011), in wine and brewery industry for improving 
the quality and yield of the fermented product (Singh et al., 2007; Galante et al., 1998; Bamforth, 2009), in food processing industry for the improvement of extraction procedure, cloud stability, texture and clarification of fruit and vegetable juices (Minussi et al., 2002; Carvalho et al., 2008), in animal feed industry for the improvement of nutritional value of feed by adding the digestion process and ultimately the performance of animals (Dhiman et al., 2002), in agriculture for enhancement of crop growth by controlling plant diseases (Chet et al., 1998; Harman and Kubicek, 1998) and in detergent industry for improving colour brightness, feel and dirt removal from garments (Sukumaran et al., 2005; Singh et al., 2007; Sharyo et al., 1978).

Recombinant DNA technology played significant role for the fulfilment of industrial requirement of enzymes. Selection of appropriate expression vector and its compatibility with expression system is very important for the successful production of recombinant protein. An efficient expression system which can fulfil the industrial demand of enzyme in a limited time with low cost is required in order to meet the industrial demand (Porro et al., 2005). Optimization of conditions is another strategy being followed by scientists for the higher level production of recombinant proteins (Larentis et al., 2011; Couto et al., 2017; Mohajeri et al., 2016; Morowvat et al., 2015; Muntari et al., 2012).

Present study deals with the utilization of BL21CodonPlus (DE3) a prokaryotic expression system as expression host and pET28a having cellulase gene from T. naphthophila as expression vector for the production of recombinant cellulase. The conditions including inducer concentration, post induction time, medium composition, temperature and $\mathrm{pH}$ were analyzed for the enhanced production of recombinant cellulase.

\section{MATERIALS AND METHODS}

\section{Chemicals}

All the chemicals utilized in this study were of analytical grade and were purchased from Merck, Life Sciences, Darmstadt, Germany.

\section{Expression machinery}

Recently, we have characterized a recombinant thermostable cellulase from T. naphthophila (Khalid et al., 2019). Cellulase gene from T. naphthophila was cloned in pET28a and was expressed in BL21-CodonPlus (DE3) cells. The recombinant cells harboring the pET28a with cellulase gene from T. naphthophila were utilized for the optimizing of conditions for the maximal production of recombinant thermostable cellulase.
Production of recombinant cellulase

Regarding the production of recombinant cellulase, the overnight grown recombinant BL21-CodonPlus (DE3) cells were diluted to $1 \%$ with fresh LB medium and was incubated at $37^{\circ} \mathrm{C}$ under shaking conditions (I3000, Lab Tech, Korea) till the $\mathrm{OD}_{660}$ reached to 0.4 . The cells were induced with $1 \mathrm{~m} M$ IPTG followed by further incubation at $37^{\circ} \mathrm{C}$. The production of recombinant protein was analyzed after lyzing the cells by sonication (Sonics, Newtorn, USA) (Mansoor et al., 2018).

\section{Activity assay}

Cellulase activity was determined in $50 \mathrm{~m} M$ sodium acetate buffer ( $\mathrm{pH}$ 4.8) using carboxymethyl cellulose as substrate. The reaction mixture was incubated in water bath at $90^{\circ} \mathrm{C}$ for $30 \mathrm{~min}$. The production of monomeric sugars was estimated by DNS method. One unit of enzyme was the amount of enzyme required to liberate $1 \mu \mathrm{mol}$ of reducing sugars under the assay conditions (Miller, 1959).

\section{Optimization of conditions for the maximal cellulase production}

\section{Effect of IPTG concentration}

In order to explore the effect of inducer on the production of recombinant protein, the BL21-CodonPlus (DE3) cells were induced by varying the IPTG concentration from 0.1 to $1 \mathrm{~m} M$ and cellulase production was recorded at each IPTG concentration (Pereira et al., 2010).

\section{Effect of post-induction temperature and incubation} time

The production of recombinant cellulase was analyzed at 20,25 and $37^{\circ} \mathrm{C}$. For this purpose, the cells were shifted to respective temperature before induction after attaining the $\mathrm{OD}_{660}$ to 0.4 and were induced with 0.5 $\mathrm{m} M$ IPTG. The cellulase production was recorded at 20, 25 and $37^{\circ} \mathrm{C}$. Regarding the optimization of incubation time, the sample after induction was withdrawn after every hour and was utilized for the determination of enzyme activity (Oelschlagel et al., 2015).

\section{Effect of $p H$}

The overnight grown recombinant BL21-CodonPlus (DE3) cells were diluted to $1 \%$ with fresh LB broth prepared in $50 \mathrm{~m} M$ of each of sodium acetate buffer (35), Sodium phosphate buffer (5-7) and Tris $\mathrm{HCl}$ buffer (7-9). The cells were incubated again at $37^{\circ} \mathrm{C}$ till the achievement of $\mathrm{OD}_{660}$ to 0.4 and were induced with 0.5 $\mathrm{m} M$ IPTG followed by further incubation at $25^{\circ} \mathrm{C}$ for $22 \mathrm{~h}$. The enzyme activity was recorded at each $\mathrm{pH}$ after losing the cells (Oelschlagel et al., 2015). 


\section{Effect of supplementation of medium}

Various carbon sources including glucose, sucrose, lactose, starch, fructose \& maltose and nitrogen sources including yeast extract, tryptone, peptone, urea, glycine and inorganic nitrogen sources including ammonium chloride and ammonium sulphate were utilized for the supplementation of LB medium at a final concentration of $1 \%$. The overnight grown recombinant BL21-CodonPlus (DE3) cells having recombinant pET28a were diluted to $1 \%$ with the LB medium supplemented with additional carbon and nitrogen sources separately. The cells were induced with $0.5 \mathrm{mM}$ IPTG and the expression of recombinant protein was analyzed at $25^{\circ} \mathrm{C}$ after $22 \mathrm{~h}$ of incubation (Zhang et al., 2009).

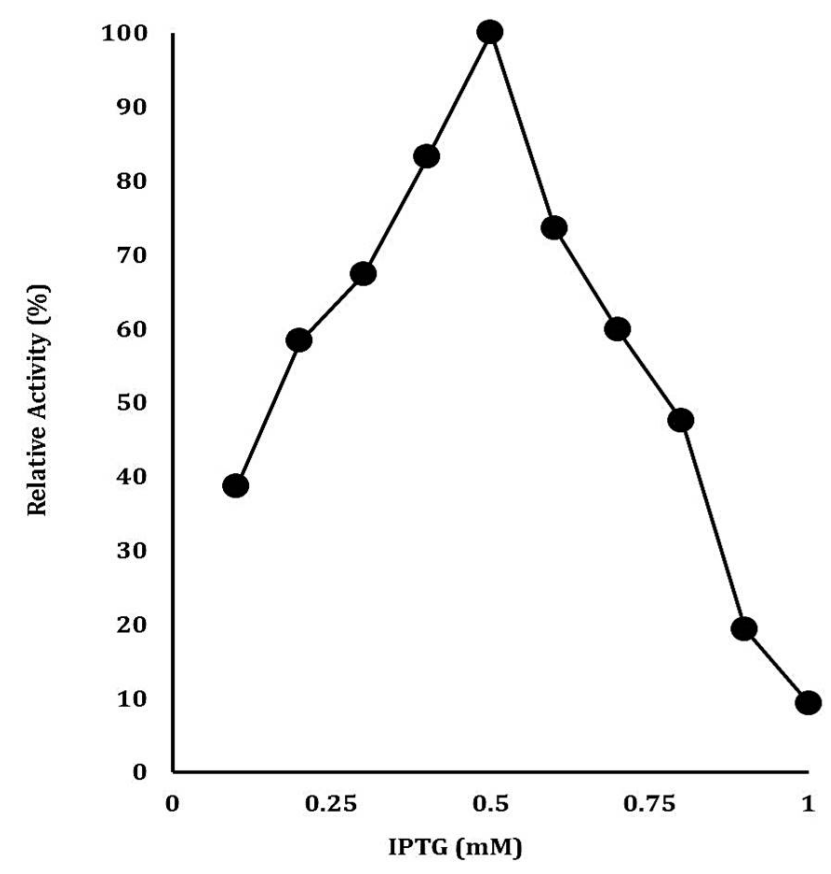

Fig. 1. Optimization of IPTG concentration for the maximal production of recombinant cellulase The data on $\mathrm{X}$-axis shows the IPTG concentration $(\mathrm{m} M)$ whereas on Y-axis shows the relative activity (\%).

\section{RESULTS AND DISCUSSIONS}

Prokaryotic expression system is being preferred over eukaryotic expression system due to its low cost, rapid growth rate, flexibility and ease to scale up for higher level production of proteins which don't require post translational modifications (Porowinska et al., 2013). More over optimization of conditions is another strategy along with the suitable expression system for eminent production of recombinant proteins. IPTG is an inducer molecule, commonly utilize for production of recombinant protein being produced under the lac operon. Current study demonstrated the enhanced production of recombinant protein with the increase in IPTG concentration. Maximal cellulase production was achieved at $0.5 \mathrm{mM}$ IPTG while further increase in IPTG resulted in reduced enzyme production (Fig. 1). The reduced production of recombinant cellulase at higher concentration of IPTG is due to its toxicity to cell and its ability to diminish the rate of synthesis of ribosomal RNA (Rizkia et al., 2015). These results are in agreement with the previous report for the production of cellulases from E. cellulosolvens (Yoda et al., 2005), C. saccharolyticus (Park et al., 2011) and T. maritima (Pereira et al., 2010) whereas in contrast to this, maximal cellulase production from $P$. furiosus (Kataoka and Ishikawa, 2014) was recorded at $0.1 \mathrm{~m} M$ IPTG.

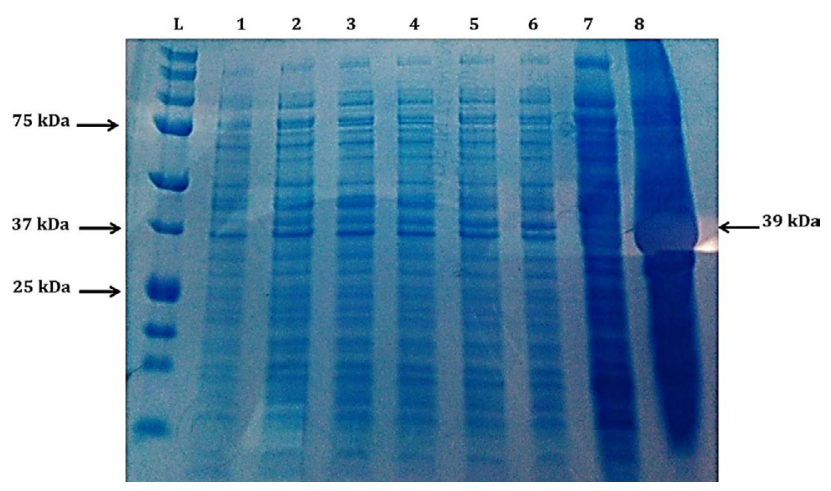

Fig. 2. Coomassie Brilliant Blue R-250 Stained SDSPAGE Gel Showing effect of incubation temperature on the production of recombinant cellulase $(39 \mathrm{kDa})$ : Lane $\mathrm{L}$, protein ladder (Precision Plus Protein Ladder, Bio RAD, USA); Lane 1, soluble fraction after lysis of cells having pET28a without insert as negative control; Lane 2-6, Soluble part after lysis of cells having pET28a with cellulase gene with post induction period of $1-5 \mathrm{~h}$ at $37^{\circ} \mathrm{C}$; Lane 7, soluble part after lysis of cells having pET28a with cellulase gene with post induction period of $22 \mathrm{~h}$ at $20^{\circ} \mathrm{C}$; Lane 8, soluble part after lysis of cells having pET28a with cellulase gene with post induction period of $22 \mathrm{~h}$ at $25^{\circ} \mathrm{C}$.

Optimization of post induction incubation temperature is important for the higher level production of recombinant protein in soluble form. The recombinant protein was produced mainly as insoluble inclusion bodies at $37^{\circ} \mathrm{C}$ and the expression of recombinant cellulase was quite low at $20^{\circ} \mathrm{C}$ whereas the maximal soluble production of recombinant protein was achieved at $25^{\circ} \mathrm{C} \mathrm{(Fig.} \mathrm{2)} \mathrm{after}$ $22 \mathrm{~h}$ of incubation (Fig. 3). We could produce maximum of 18,28 and $08 \mathrm{U} / \mathrm{mL}$ of recombinant cellulase at 20, 25, $37^{\circ} \mathrm{C}$, respectively. This strategy of expressing protein at low temperature with extended incubation time was previously reported by Rincon et al. (2017), Tayyab et al. 
(2011) and Zhang et al. (2009). Cellulases from T. maritima (Pereira et al., 2010), Acidothermus cellulolyticus (Wang et al., 2015), Eubacterium cellulosolvens (Yoda et al., 2005) and Fervibacterium nodosum (Wang et al., 2010) showed their optimal production under low temperature between 16 to $28^{\circ} \mathrm{C}$ whereas cellulase from Caldicellulosiruptor saccharolyticus (Park et al., 2011) showed its high level production at $30^{\circ} \mathrm{C}$ with overnight incubation.

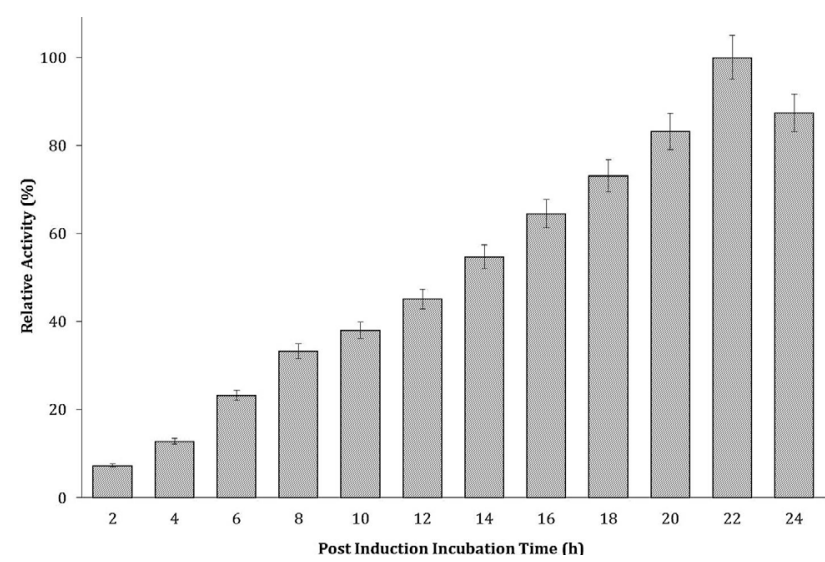

Fig. 3. Effect of post induction incubation time on recombinant cellulase production. Experiment was conducted at $25^{\circ} \mathrm{C}$. The data on $\mathrm{X}$-axis shows the post induction incubation time $(\mathrm{h})$ and $\mathrm{Y}$-axis shows the relative activity $(\%)$.

Table I.- Effect of various carbon and nitrogen sources on the production of recombinant cellulase.

\begin{tabular}{llc}
\hline Sources & & Relative activity (\%) \\
\hline Carbon & Control & 100 \\
sources & Glucose & 163 \\
& Maltose & 161 \\
& Lactose & 153 \\
& Sucrose & 127 \\
& Fructose & 109 \\
& Starch & 105 \\
Nitrogen & Control & 100 \\
sources & Yeast extract & 197 \\
& Tryptone & 171 \\
& Peptone & 120 \\
& Ammonium sulphate & 40 \\
& Ammonium chloride & 38 \\
& Urea & 34 \\
& Glycine & 23 \\
\hline
\end{tabular}

Change in $\mathrm{pH}$ always shows significant influence on the growth of bacteria. No significant bacterial growth or cellulase production was recorded at $\mathrm{pH} 3$ or 4 . However the cellulase production was increased with the increase in $\mathrm{pH}$ beyond 5 and maximal cellulase production was recorded at $\mathrm{pH} 7$ while further increase in $\mathrm{pH}$ resulted in reduced enzyme production (Fig. 4). These findings are in agreement with the findings of Oelschlagel et al. (2015) while according to other reports optimal production of recombinant proteins was recorded at $\mathrm{pH} 7.5$ (Wang et al., 2014; Zhang et al., 2009; Mendoza et al., 2014).

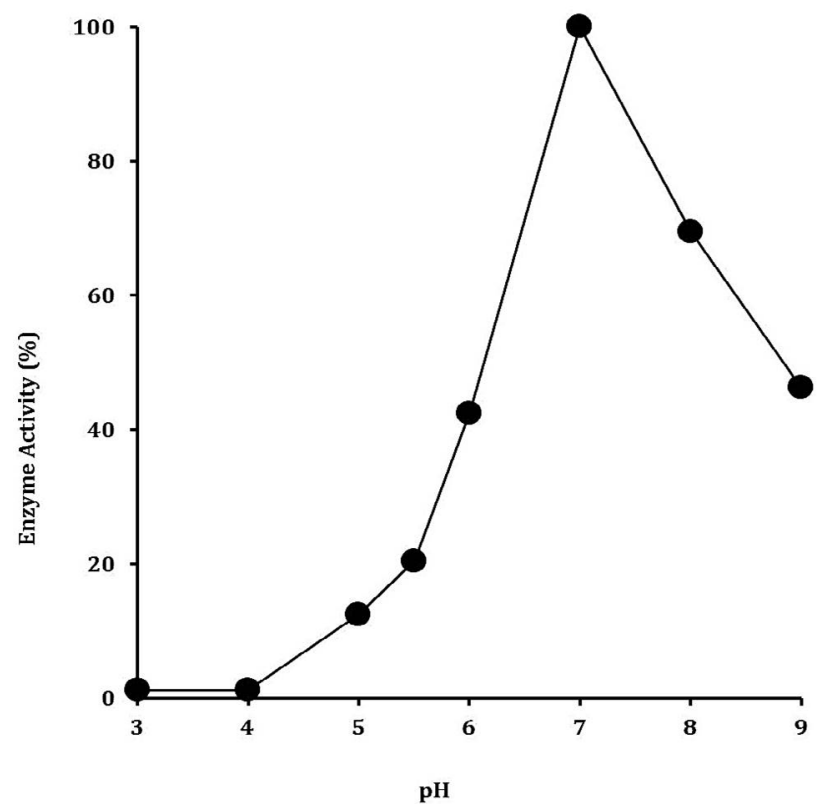

Fig. 4. Optimization of $\mathrm{pH}$ for the maximal production of recombinant cellulase The cellulase production was analyzed in $50 \mathrm{~m} M$ of each of sodium acetate buffer (3-5), sodium phosphate buffer (5-7) and Tris $\mathrm{HCl}$ buffer (7-9). The data on $\mathrm{X}$-axis indicates the buffer $\mathrm{pH}$ values while on Y-axis show relative activity (\%).

Medium supplementation with various carbon and nitrogen sources showed the enhanced production of recombinant cellulase. The high level production of recombinant protein was achieved when the medium was supplemented with glucose or maltose at a final con centration of $1 \%$. The results depicted that glucose or maltose are carbon sources being preferred by BL21CodonPlus (DE3) cells for their growth and for the production of recombinant protein (Table I). This is might be due to their monomeric nature and ease in absorption as compared to lactose or sucrose (disaccharides) and starch (polysaccharide). Similarly, aldo-sugars are being preferred over keto-sugars by BL21-CodonPlus (DE3) cells for their growth. These results are in agreement with previous reports by Nur et al. (2016), Bren et al. (2016), Wang et al. (2015) and Bettenbrock et al. (2007). Production of 
recombinant cellulase was also enhanced when the LB medium was supplemented with yeast extract or tryptone as additional nitrogen sources whereas the rest of selected nitrogen sources could not contribute significantly in the production of recombinant protein (Table I). The results demonstrated that BL21-CodonPlus (DE3) cells preferred organic nitrogen sources over inorganic nitrogen sources for the growth (Table I). These results are in agreement with previous reports by $\mathrm{Fu}$ et al. (2006), Zhang et al. (2009), Mahmoudi et al. (2012) and Lee and Chang (1994), who observed the higher level cellular growth and the enhanced production of recombinant protein when the medium was supplemented with yeast extract and tryptone, respectively.

\section{CONCLUSION}

This study demonstrated the optimization of conditions for the enhanced production of recombinant thermostable cellulase using a prokaryotic expression system. Optimization studies revealed the highest cellulase activity when recombinant cells were induced with 0.5 mM IPTG with post induction incubation of $22 \mathrm{~h}$ at $25^{\circ} \mathrm{C}$ $(28 \mathrm{U} / \mathrm{mL})$ in the presence of $50 \mathrm{~m} M$ sodium phosphate buffer $\mathrm{pH} 7(37 \mathrm{U} / \mathrm{mL})$ and when the LB medium was supplemented with glucose and yeast extract as carbon and nitrogen sources $(48 \mathrm{U} / \mathrm{mL})$. Current work was a foundation study that will act as milestone for the industrial scale production of recombinant cellulase at domestic level and for the fulfilment of local industrial requirement of the enzyme in Pakistan.

\section{ACKNOWLEDGEMENTS}

This work was supported by Higher Education Commission of Pakistan.

Statement of conflict of interest

The authors have no conflict of interest.

\section{REFERENCES}

Akhtar, M., 1994. Biochemical pulping of aspen wood chips with three strains of Ceriporiopsis subvermispora. Holzforschung, 48: 199-202. https://doi.org/10.1515/hfsg.1994.48.3.199

Bamforth, C.W., 2009. Current perspectives on the role of enzymes in brewing. J. Cereal Sci. Sp. Sec.: Enzymes Grain Process, 50: 353-357. https://doi. org/10.1016/j.jcs.2009.03.001

Bettenbrock, K., Sauter, T., Jahreis, K., Kremling, A., Lengeler, J.W. and Gilles, E.D., 2007. Correlation between growth rates, EIIACrr phosphorylation and intracellular cyclic AMP levels in Escherichia coli K-12. J. Bact., 189: 6891-6900. https://doi. org/10.1128/JB.00819-07

Bhat, M.K., 2000. Cellulases and related enzymes in biotechnology. Biotechnol. Adv., 18: 355-383. https://doi.org/10.1016/S0734-9750(00)00041-0

Bren, A., Park, J.O., Towbin, B.D., Dekel, E., Rabinowitz, J.D. and Alon, U., 2016. Glucose becomes one of the worst carbon sources for $E$. coli on poor nitrogen sources due to suboptimal levels of cAMP. Scient. Rep., 6: 24834. https://doi. org/10.1038/srep24834

Carvalho, L.M.J., Castro, I.M. and Silva, C.A.B., 2008. A study of retention of sugars in the process of clarification of pineapple juice (Ananas comosus, L. Merril) by micro- and ultra-filtration. J. Fd. Engin., 87: 447-454. https://doi.org/10.1016/j. jfoodeng.2007.12.015

Chet, I., Benhamou, N. and Haran, S., 1998. Mycoparatism and lytic enzymes. In: Trichoderma and Gliocladium enzymes (eds. G.F. Harman and C.P. Kubicek). Taylor \& Francis, London, UK, pp. 327-342.

Couto, M.R., Rodrigues, J.L. and Rodrigues, L.R., 2017. Optimization of fermentation conditions for the production of curcumin by engineered Escherichia coli. J. R. Soc., 14: e0470. https://doi.org/10.1098/ rsif.2017.0470

Deguchi, S., Tsujii, K. and Horikoshi, K., 2006. Cooking cellulose in hot and compressed water. Chem. Commun., 31: 3293-3295. https://doi.org/10.1039/ b605812d

Dhiman, T.R., Zaman, M.S., Gimenez, R.R., Walters, J.L. and Treacher, R., 2002. Performance of dairy cows fed forage treated with fibrolytic enzymes prior to feeding. Anim. Feed Sci. Technol., 101: 115-125. https://doi.org/10.1016/S03778401(02)00177-3

Fu, X.Y., Wei, D.Z. and Tong, W.Y., 2006. Effect of yeast extract on the expression of thioredoxinhuman parathyroid hormone from recombinant Escherichia coli. J. Chem. Technol. Biotechnol., 81: 1866-1871. https://doi.org/10.1002/jctb.1615

Galante, Y.M., De, C.A. and Monteverdi, R., 1998. Application of Trichoderma enzymes in the food and feed industries. In: Trichoderma and liocladium (eds. G.E. Harman and C.P. Kubicek). Taylor \& Francis, London, UK, pp. 327-342.

Gupta, R., Khasa, Y.P. and Kuhad, R.C., 2011. Evaluation of pretreatment methods in improving the enzymatic saccharification of cellulosic 
materials. Carbohydr. Polym., 84: 1103-1109. https://doi.org/10.1016/j.carbpol.2010.12.074

Harman, G.E. and Kubicek, C.P., 1998. Trichoderma and Gliocladium enzymes, Volume 2: Biological control and commercial applications. Taylor \& Francis, London, UK.

Kang, H.K., Kim, N.M., Kim, G.J., Seo, E.S. and Ryu, H.J., 2011. Enhanced saccharification of rice straw using hypochlorite-hydrogen peroxide. Biotechnol. Bioproc. Engin., 16: 273-281. https:// doi.org/10.1007/s12257-010-0262-1

Karmakar, M. and Ray, R.R., 2011. A statistical approach for optimization of simultaneous production of $\beta$-Glucosidase and endoglucanase by Rhizopus oryzae from solid-state fermentation of water hyacinth using central composite design., Biotechnol. Res. Int., 6: 41-53. https://doi. org/10.4061/2011/574983

Kataoka, M. and Ishikawa, K., 2014. A new crystal form of a hyperthermophilic endocellulase. Acta Crystallogr. Sect. F: Struct. Biol. Commun., 70: 878883. https://doi.org/10.1107/S2053230X14010930

Khalid, A., Tayyab, M., Shakoori, A.R., Hashmi, A.S., Yaqub, T., Awan, A.R., Wasim, M., Firyal, S., Hussain, Z. and Ahmad, M., 2019. Cloning, expression and characterization of highly active recombinant thermostable cellulase from Thermotoga naphthophila. Pakistan J. Zool., 51: 925-934, 2019. http://dx.doi.org/10.17582/journal. pjz/2019.51.3.925.934

Koomnok, C., 2005. Selection of cellulase producing thermophilic fungi. In: Proceedings of the $31^{\text {st }}$ Congress on Science and Technology of Thailand of Technology. Suranaree University.

Kuhad, R.C., Gupta, R. and Khasa, Y.P., 2010. Bioethanol production from lignocellulosic biomass: An overview. In: Wealth from waste (ed. B. Lal). Teri Press, New Delhi, India.

Larentis, A.L., Argondizzo, A.P.C., Santos, E.G., Jessouron, E., Galler, R. and Medeiros, M.A., 2011. Cloning and optimization of induction conditions for mature PsaA (Pneumococcal Surface Adhesion A) expression in Escherichia coli and recombinant protein stability during long-term storage. Protein Exp. Purif., 78: 38-47. https://doi.org/10.1016/j. pep. 2011.02 .013

Lee, S.Y. and Chang, H., 1994. Effect of complex nitrogen source on the synthesis and accumulation of poly (3-hydroxybutyric acid) by recombinant Escherichia coli in flask and fed-batch cultures. $J$. Polym. Environ., 2: 169-176.

Mahmoudi, S., Abtahi, H., Bahador, A., Mosayebi,
G., Salmanian, A.H. and Teymuri, M., 2012. Optimizing of nutrients for high level expression of recombinant streptokinase using $\mathrm{pET} 32 \mathrm{a}$ expression system. J. clin. Med., 7: 241-246. https://www.ncbi. nlm.nih.gov/pubmed/23400422

Mansoor, S., Tayyab, M., Jawad, A., Munir, B., Firyal, S., Awan, A.R., Rashid, N. and Wasim, M., 2018. Refolding of misfolded inclusion bodies of recombinant $\alpha$-amylase: Characterization of cobalt activated thermostable $\alpha$-amylase from geobacillus SBS-4S. Pakistan J. Zool,, 50: 1147-1155. http://dx.doi.org/10.17582/journal. pjz/2018.50.3.1147.1155

Mendoza C.A., Castro, A.R.M., Olvera, A., Zavala, G., Mendoza, V.M., Garcia, H.E., Alagon, A., Trujillo, R.M.A. and Valdez, C.N.A., 2014. Influence of pH control in the formation of inclusion bodies during production of recombinant sphingomyelinase-D in Escherichia coli. Microb. Cell Factor, 13: 137. https://doi.org/10.1186/s12934-014-0137-9

Miller, G.L., 1959. Use of dinitrosalicylic acid reagent for determination of reducing sugar. Anal. Chem., 31: 426-428. https://doi.org/10.1021/ac60147a030

Minussi, R.C., Pastore, G.M. and Duran, N., 2002. Potential applications of laccase in the food industry. Trends Fd. Sci. Technol., 13: 205-216. https://doi.org/10.1016/S0924-2244(02)00155-3

Mohajeri, A., Soltanahmadi, Y.P., Abdolalizadeh, J., Karimi, P. and Zarghami, N., 2016. Effect of culture condition variables on human endostatin gene expression in Escherichia coli using response surface methodology. Jundishapur J. Microbiol., 9: 8. https://doi.org/10.5812/jjm.34091

Morowvat, M.H., Babaeipour, V., Memari, H.R. and Vahidi, H., 2015. Optimization of fermentation conditions for recombinant human interferon beta production by Escherichia coli using the response surface methodology. Jundishapur J. Microbiol., 8: e16236. https://doi.org/10.5812/ jjm.8(4)2015.16236

Muntari, B., Amid, A., Mel, M., Jami, M.S. and Salleh, H.M., 2012. Recombinant bromelain production in Escherichia coli: process optimization in shake flask culture by response surface methodology. AMB Express, 2: 12. https://doi.org/10.1186/21910855-2-12

Nur, I., Tahera, J., Munna, M.S., Rahman, M. and Noor, R., 2016. Impact of different carbon sources on the in vitro growth and viability of Escherichia coli (SUBE01) and Salmonella spp. (SUBS01) cells. Bangladesh J. Microbiol., 32: 39-44. https://doi. org/10.3329/bjm.v32i0.28476 
Oelschlagel, M., Heiland, C., Schlömann, M. and Tischler, D., 2015. Production of a recombinant membrane protein in an Escherichia coli strain for the whole cell biosynthesis of phenylacetic acids. Biotechnol. Rep., 7: 38-43. https://doi. org/10.1016/j.btre.2015.05.002

Park, J.I., Kent, M.S., Datta, S., Holmes, B.M., Huang, Z., Simmons, B.A., Sale, K.L. and Sapra, R., 2011. Enzymatic hydrolysis of cellulose by the cellobiohydrolase domain of CelB from the hyperthermophilic bacterium Caldicellulosiruptor saccharolyticus. Bioresour. Technol., 102: 5988-5994. https://doi.org/10.1016/j. biortech.2011.02.036

Pereira, J.H., Chen, Z., McAndrew, R.P., Sapra, R., Chhabra, S.R., Sale, K.L., Simmons, B.A. and Adams, P.D., 2010. Biochemical characterization and crystal structure of endoglucanase Cel5A from the hyperthermophilic Thermotoga maritima. J. Struct. Biol., 172: 372-379. https://doi. org/10.1016/j.jsb.2010.06.018

Porowinska,D., Wujak,M., Roszek,K. andKomoszynski, M., 2013. Prokaryotic expression systems. Postepy Hig. Med. Doswiadczalnej Online, 67: 119-129. https://doi.org/10.5604/17322693.1038351

Porro, D., Sauer, M., Branduardi, P. and Mattanovich, D., 2005. Recombinant protein production in yeasts. Mol. Biotechnol., 31: 245-259. https://doi. org/10.1385/MB:31:3:245

Rincon, D.D.J., Duque, I., Osorio, E., Rodriguez L.A., Espejo, M.A., Parra, G.C.M., Poutou, P.R.A., Almeciga, D.C.J. and Quevedo, H.B., 2017. Production of recombinant Trichoderma reesei cellobiohydrolase II in a new expression system based on Wickerhamomyces anomalus. Enzyme Res., 2017: 6980565. https://doi. org/10.1155/2017/6980565

Rizkia, P.R., Silabana, S., Hasanc, K., Kamaraa, D.S., Subrotoa, T., Soemitroa, S. and Maksum, I.P., 2015. Effect of Isopropyl- $\beta$-D-thiogalactopyranoside concentration on prethrombin-2 recombinan gene expression in Escherichia coli ER2566. Procedia Chem., 17: 118-124. https://doi.org/10.1016/j. proche.2015.12.121

Sharyo, M., Sakaguchi, H. and Ohishi, M., 1978. Method of making sanitary paper from chemical pulp using a single component cellulase that does not contain cellulose-building domain. US Patent 6468391.

Singh, A., Kuhad, R.C. and Ward, O.P., 2007. Industrial application of microbial cellulases, In: Lignocellulose biotechnologgy: Future prospects (eds. R.C. Kuhad and A. Singh). I.K. International Publishing House, New Delhi, India, pp. 345-358.

Sreenath, H.K., Shah, A.B., Yang, V.W., Gharia, M.M. and Jeffries, T.W., 1996. Enzymatic polishing of jute/cotton blended fabrics. J. Ferment. Bioeng., 81: 18-20. https://doi.org/10.1016/0922338X(96)83113-8

Sukumaran, R.K., Singhania, R.R. and Pandey, A., 2005. Microbial cellulases production, applications and challenges. J. scient. indust. Res., 64: 832-844.

Tayyab, M., Rashid, N., Angkawidjaja, C., Kanaya, S. and Akhtar, M., 2011. Highly active metallocarboxypeptidase from newly isolated Geobacillus strain SBS-4S: Cloning and characterization. J. Biosci. Bioeng., 3: 259-265. https://doi.org/10.1016/j.jbiosc.2010.11.002

Wang, H., Wang, F., Wang, W., Yao, X., Wei, D., Cheng, H. and Deng, Z., 2014. Improving the expression of recombinant proteins in E. coli BL21 (DE3) under acetate stress: An alkaline $\mathrm{pH}$ shift approach. PLoS One, 9: e112777. https://doi.org/10.1371/journal. pone. 0112777

Wang, J., Gao, G., Li, Y., Yang, L., Liang, Y., Jin, H., Han, W., Feng, Y. and Zhang, Z., 2015. Cloning, expression and characterization of a thermophilic endoglucanase, AcCel12B from Acidothermus cellulolyticus 11B. Int. J. mol. Sci., 16: 2508025095. https://doi.org/10.3390/ijms 161025080

Wang, J., Wen, B., Xu, Q., Xie, X. and Chen, N., 2015. Optimization of carbon source and glucose feeding strategy for improvement of L-isoleucine production by Escherichia coli. Biotechnol. Biotechnol. Equip., 29: 374-380. https://doi.org/10. 1080/13102818.2015.1006899

Wang, Y., Wang, X., Tang, R., Yu, S., Zheng, B. and Feng, Y., 2010. A novel thermostable cellulase from Fervidobacterium nodosum. J. Mol. Catal. Enzym., 66: 294-301. https://doi.org/10.1016/j. molcatb.2010.06.006

Yoda, K., Toyoda, A., Mukoyama, Y., Nakamura, Y. and Minato, H., 2005. Cloning, sequencing, and expression of a Eubacterium cellulosolvens 5 gene encoding an endoglucanase (Cel5A) with novel carbohydrate-binding modules and properties of Cel5A. Appl. environ. Microbiol. 71: 57875793. https://doi.org/10.1128/AEM.71.10.57875793.2005

Zhang, H.B., Mao, X.Q., Wang, Y.J. and Hu, X.Q., 2009. Optimization of culture conditions for highlevel expression of dextransucrase in Escherichia coli. J. Fd. Agric. Environ., 7: 75-78. 